\title{
Millennial Awareness of the Environmental Impacts of Tin Mining in Bangka
}

\author{
Rini Archda Saputri ${ }^{1}$, Ibrahim ${ }^{2}$, Sandy Pratama ${ }^{3}$, Sarpin $^{4}$ \\ \{riniardhasaputri@gmail.com ${ }^{1}$,iim_babel@yahoo.com ${ }^{2}$, sandy-djarib@yahoo.co.id ${ }^{3}$, \\ sarpinfarras@gmail.com ${ }^{4}$ \} \\ Universitas Bangka Belitung, Indonesia ${ }^{1,2,3,4}$
}

\begin{abstract}
Tin mining in Bangka has been going on for Centuries. The Bangka people Themselves have embedded the term tin mining as the "Datuk" that Destroys the earth roommates Refers to uncontrolled tin mining and has brought about a very critical and causing environmental degradation. Change in the landscape of Bangka. The debate and controversy over environmental damage due to mining activities in Bangka has been intense, involving various actors and protracted. To a greater extent, debates linking issues with environmental damage mining in Bangka by actors (government, business people, and society) are understood as the socio-economic and political conflicts. In debates linking tin mining with environmental damage, a different political attitude emerged between the protest and accommodative politics of the forms of tin mining companies by tin mining in Bangka. This study aims to look at the awareness and the role of Millennials as the younger generation related to the problem of environmental degradation activities caused by tin mining in Bangka.
\end{abstract}

Keywords: Tin Mining, Environmental Damage of Tin Mining, Millennial Awareness of the Environment.

\section{Introduction}

Indonesia is a country that produces $25 \%$ of the total needs of the international tin $(200,000$ tons per year) and mostly comes from Bangka tin. Bangka is the region's largest tin producer in Indonesia. Tin has been mined since three centuries ago and is under the control of different regimes. However, debates are controversial and long about control over mining, marketing, and impact on the environment, emerging in the reform era. This condition occurs when the liberalization in the control system of exploitation and marketing of tin. In addition to the two old companies, PT. Timah Bangka Tbk and PT. Koba Tin established a new mining companies and illegal tin mining, which are known as Mine Unconventional (TI). The presence of the new private mining companies and mining IT has been able to compete with the production of both old monopolize this business for a long time. At the same time, the new mining system was so greedy for profit as quickly as possible in a relatively short time without regard to the environmental impact [1].

Such a condition was not without reason. The condition is caused by a dramatic change in control over the resources of tin that occurred after the reform era. Minister of Industry and Trade issued a decision that no longer includes the word 'lead' in the list of export goods supervised or regulated by the government. Ministry of Industry and Trade are interpreted by various parties; businesses, local governments, and communities Bangka as the beginning of a 
new era in and the beginning of the release of government control at all levels; from production to marketing. The decision has been made every person feel entitled to take, possess and sell even lead, an activity that is prohibited from 1819 to 1995 . In fact, during the New Order government,

Ministry of Industry and Trade was responded by Regent Pacific in that time, Eko Maulana Ali by issuing Regulation (Perda) No. 6 of 2001 which gives the public access to Bangka to mine. According to him, the local government has the right to permit the public mining to mine. Loss of control and liberalization in the Bangka tin mining system has resulted in a very greedy mining operations, short-term profit-oriented and result in a critical environment.

Unconventional tin mining in Bangka Island has been going on since 2000. This activity is carried out by people or businesses without permission from the government. In 2002 the amount of lead Unconventional about 6,000 units scattered throughout the island of Bangka. This activity has a huge impact on the aquatic ecosystem and the surrounding communities. This activity has a very bad impact on the aquatic ecosystem such as 1) sedimentation and changes in the landscape of coastal areas, 2) increasing the fertility of the waters, 3) an increase in turbidity, 4) destruction of ecosystems and the extinction of aquatic biota, and 5) heavy metal pollution. Unconventional tin mining case is feared to be an iceberg that could someday become Atar horizontal conflicts among communities.

Resources lead a mainstay commodity Bangka Belitung Province which began in the 17 th century by the Dutch government and the Indonesian government officially administered in 1952. Since 1976 the tin mining activities handled by PT. Tin Mine until now [2]. Various changes in the national political structure (including decentralization of government power) and in the structure and performance of the national economy, a very dramatic impact on the management of tin mining in this area. Field observations indicate illegal mining was likely growing wild. It is estimated that in 2002 the number of unconventional mining around 6000 units spread across the island of Bangka. (PPLH IPB and Bappedalda Bangka, 2002) [2].

Like two sides of a coin, tin mining, of course, have positive and negative effects, has benefits and disadvantages. The positive impact among others as a source of foreign exchange, a provider of employment and business opportunities as well as improving the economy. The negative impact of tin mining activities, among others, the decline in soil quality and quantity of natural vegetation types, the loss of royalties countries $(3 \%)$ reached $\$ 13.5$ million per year, not including other taxes due to the export of tin-free without the brand has open smuggling, so the tin unhealthy business [1]. Besides, the tin mining can also lead to sociological impact that a change in the culture and local customs [3].

The changing landscape of Bangka and environmental damage caused by the mining of tin is not a new problem. At least, this problem has been reported since the mid-19th century by the German doctor, Franz Epp [4], which served in the Pacific. Then, followed by JA report Schuurman [5], and Karl Helbig [6], a German geographer who lived in a different era, cynically reported that "Bangka has many rivers but the lack of clean water".

In addition to the changing landscape, the environmental degradation caused by mining activities is inevitable. The rise of the level of environmental damage caused by greedy looting in various places around the Bangka and in areas reclaimed by PT. Timah Bangka Tbk. Damage to the environment has reached the tipping point, where there are around $30 \%$ of severe damage to forests in the Pacific and $5 \%$ of it as a result of mining activities Unconventional (TI). While it is critical lands in the Pacific has reached 1,642,414 hectares. The problem is not about the size of the land area or the percentage of degraded land, but the real danger is the environmental damage that the increasing intensity and has reached the 
critical stage. Degraded forest has been aggravated by the polluted river. There are eleven major rivers polluted and have changed color to milky coffee. This does not include the IT to damage the Regional Water Company in Louth and Toboali city.

In short, Bangka Belitung (Babel) was formed in November 2000 in a short time has become the province of "battered (Babylon)". The question now is how the reaction of stakeholders, such as governments, major mining companies, and local communities for the severe environmental conditions? Many studies that discuss political relations and the mine environment from multiple perspectives. Hyndman [7] and Kirsch [8] says that the mine has created environmental problems and the public response to the ecological crisis is seen as an ecological resistance. From the research results in the journal, it seems clear that the policy of state actors in addressing the problem of environmental damage is not as simple as it seems on the surface. There are political and economic competition that is hidden behind controversial debates regarding IT mining and environmental damage. Handling problems in the management of the mine and the issue of environmental damage appears to be more politicized and are under conditions where the governmental actors compete with each other in their efforts to gain political access and the wider economy.

Tug regulation tin problem that does not go over at the top level, between the Central Government and Local Government as well as in the District Government itself so IT with all its problems continue to run. As a result, the impact on the environment due to the social conditions of tin mining, which is done on a large scale in various areas in Bangka Belitung Islands continues to run. The focus of the study in this paper is to analyze the environmental impact of tin mining in Bangka, as well as see how the millennial as the younger generation plays a role in this regard. Do young people in the Pacific have awareness and knowledge of the environmental impacts of mining activities? And how young people take part in these issues.

\section{Research Method}

The research approach used in this study is qualitative, in which researchers act as a key instrument. Data collected in two ways. First, to answer the question of the environmental impact of tin mining in Bangka, researchers used a literature study on the results of previous studies, in the form of journals, books, news media, print and electronic. Then the second, to see the extent of knowledge/awareness of the millennial (youth) against the environmental impact of tin mining in Bangka, researchers deploy questionnaires. The object of this research is the millennial (youth) which in this case is a university student in Bangka Belitung.

\section{Result and Discussion}

\subsection{Environmental Impact Tin Mining in the Pacific}

Open-pit mining systems which are at ground level a lot to change the landscape and the ecosystem balance the soil surface, then under Law No. 41/1999, Article 38, Paragraph 4, the system of open-pit mining is prohibited in the protected areas. Herman et al (2009) stated that the tin mining activities in Bangka Belitung Islands conducted fully has led to changes in the environment by decreasing soil productivity and the quality of the environment [9]. 
Changes that occur post-mining environment, in addition to changes in the landscape also the result of accumulation of soil quality after mining. Cover damaged soil structure as before, also topsoil mixed or sunset in the deeper layers. Topsoil replaced the soil of the bottom layer are less fertile, otherwise fertile top layer is in the bottom layer. Likewise, biological populations of land in the topsoil be set, so that the missing/dead and not working properly. Carrying capacity of the post-mining topsoil for plant growth to below. Dariah et al. [10] states that the general planning for the closure (including reclamation) is not integrated with mining operations since the beginning until closing so that post-mining arise various problems. For the handling of mining activities should be done in an open system integrated with fixed preserving land for the value of the function's further along in its implementation [9].

Open-pit mining system (open pit mining) was done by stripping mine overburden material. Overburden removed from mining areas and mining materials excavated and hauled out. Once all the minerals removed, then there is the rest of the holes dug in the form of underunder. At the company licensed mining rights (KP), under-under pit is backfilled with soil taken from the ground or on the ground around the previous closing. If the back closure is done quite right, then the topsoil that has high fertility mixed with other ground or buried at the bottom. On the contrary-soil (subsoil) which has not been progressing (infertile) it is in the top layer. Former soil bearing capacity of this conventional open pit mining system becomes low and open to the damaged soil structure, so the opportunity to erosion. Finnel [11] found that the loss of topsoil a few centimeters can reduce productivity by $40 \%$ on fertile soil, and $60 \%$ in poor soils.

Besides, the tin mining in Bangka has caused much damage to the environment, including rivers. Water quality, aquatic habitat and the diversity of threatened fish resources as well as systems of local wisdom that there is also disturbed. Results of previous studies show that tin mining affects water quality, especially the brightness, turbidity, and total suspended solids. Based on the value of IP streams in tin mining areas indicate moderate polluted and habitat conditions in heavy interference conditions. Low water quality due to sedimentation of tin mining waste resulting in reduced biodiversity and species composition of fish in the waters. While the system of indigenous communities survives while complying with the customary rules even though the water has been disturbed.

Tin mining in Bangka has caused environmental damage to waters of the natural habitats of fish resources. Data show that most of the rivers in the Pacific in damaged condition and critical. Tin mining activities around the river would threaten fish habitat. Fish are organisms that are sensitive and vulnerable to environmental changes [12]. Changes in aquatic environments such as physical factors [13], chemistry and biology [14] greatly affect the composition and distribution of the existing fish. In the affected areas as a result of tin mining sedimentation, fish diversity is expected to decline [15].

Tin mining activities affect the environmental conditions of the river, which led to high levels of pollution and lower the index value and effect subsequent habitat is declining fish species diversity [16]. Impacts of mining activities:

a) Sedimentation and Coastal Area Landscape Change. Almost all rivers on the island of Bangka switch functions as container waste from tin mining. Estuary, river bottom slope be relatively small as a result of sand deposits of other materials so that the storage capacity of the river to be reduced. Sedimentation in a body of water can affect others on the advance of silting and landscape change seabed, the fertility of the waters, and the loss of aquatic biodiversity. High sedimentation in coastal areas has led to changes in the 
landscape in the beach area. This is due, the tin mining in the headwaters and along the coast of the island of Bangka.

b) Fertility Bodies. When tin mining begins, the surface soil layer rich in humus appointed to facilitate the digging. After the excavation reached a depth of approximately 2-3 m, further excavations carried out by machine or manually. Land taken subsequently performed washing and screening process that can lead separately from the ground. The organic material originating from these leaching will then be carried away by the water into the rivers around the mine site. The influx of organic material into waters of the river in excessive amounts can cause fertility perairan to be high, so it will stimulate blooming (blow) populations of phytoplankton and water are pathogenic microbes. Waste nutrients and organic matter either in the form of dissolved and particulate matter, comes from feed that is not eaten and excretion of fish, which are generally characterized by an increase in total suspended solids (TSS), biological oxygen demand (BOD6), chemical oxygen demand (COD), and the content of $\mathrm{C}, \mathrm{N}$, and $\mathrm{P}$. potentially, the spread of sewage rich affect nutrients and organic material can be increasing sedimentation and siltation, hypoxia, hyper-nitrification, and changes in productivity and benthic community structure.

c) Increased turbidity. River turbidity mainly on Bangka Island in general, due to lead activities Unconventional around the island. Turbidity is the most noticeable impact of mining activities caused by particle-particle soil dissolved or suspended in water. The impact of turbidity can lead to fish kills due to damage respiratory equipment as well as damage to spawning and rearing areas for aquatic organisms, especially fish.

d) Ecosystem Damage and Loss of Aquatic Biota Impact hoarding by sediment (sedimentation) occurring in the waters either directly or indirectly related to the existence of biodiversity. Penibunan seabed sediment can damage and destroy the benthic animal communities' spawning location and other aquatic biota. The suspended soil particles will cover habitat (aquatic plants, the soil surface) and select Egg entire biota so that eggs cannot develop properly. This impact will eventually lead to mass population decline that eventually, in the long run, can degrade aquatic biodiversity

e) Heavy Metal Pollution. Public waters are particularly vulnerable to Bangka Island contaminated with lead, which is one kind of heavy metal that is very dangerous. When viewed from the process of making, washing, and processing the heavy metal contamination is likely to occur. Lead dissolved in the water body at certain concentrations will change the function of a source of toxic to aquatic life. Although the toxicity caused by a type of heavy metals on aquatic biota is not the same, but the destruction of the group resulted in interruption of the chain of life. Furthermore, the situation can certainly destroy the order of aquatic ecosystems.

Land in tin mined land dominated by quartz sand sour, very poor in nutrients, less organic matter content, it cannot hold water and the low number of microorganisms. The $\mathrm{pH}$ value of the soil surrounding the former mine is 3.6-4.6, with the content of $\mathrm{N}, \mathrm{P}$ and $\mathrm{K}$ respectively only of $0.02 \%, 2.8-3.9 \mathrm{ppm}$, and 4.9-9.6 ppm. If not corrected, this condition will not experience a natural improvement in a short period, even can reach hundreds of years to be able to be used again as cropland [3].

The environmental damage due to mining encroachment of IT to locations forbidden to be mined, such as beaches, watersheds, protected forests, gardens, and even their home page to be extracted. The fishermen lost their livelihood, because the life of not getting caught fish, the catchment area they've been tainted by TI Floating, employers such as hotels are expected to increase revenue, complained that beaches used as attraction becomes dirty and polluted 
even many beaches are missing because it eroded the IT machine. Villagers complain because of the scarcity of water in the rivers, the water becomes dirty polluted solar machine-generated IT, residents complained pollution of irrigation, plantation owners harmed because most of their land has been turned into a small under-under excavated area of IT.

The effectiveness of post-mining reclamation program carried out by PT. Timah Tbk can be seen from the reconstruction program of land, land rehabilitation and revegetation of land. Reclamation program is an obligation that must be adhered to by the company following the Regulation of the Minister of Energy and Mineral Resources No. 7 Year 2014 on the Implementation of Reclamation and Mine Closure on Business Activities of Mineral and Coal. As a state-owned company, PT. Timah is also obliged to fulfill the mandate of the Environment Act No. 31 of 2009 on the Protection and Management of the Environment [17].

Reclamation program is an activity that sought to protect the environmental damage caused by the utilization of natural resources, to manage, restore and repairing damage to the environment and ecosystems to function following its designation. In the implementation of revegetation, plant selection that needs to be done following the suitability of land, especially for land formerly used for alluvial mining activities which often impact on soil erosion [17].

Tin post-mining reclamation program carried out in Sub Merawang Bangka is ineffective. Still, the presence of IT activities (my Unconventional) found inland reclamation PT. Timah Tbk and their Illegal logging activities carried out by local people, causing ineffectiveness reclamation program run by PT. Timah. The level of public knowledge about environmental damage caused by mining activities is still lacking. This affects the level of public knowledge reclamation activities conducted by PT. Timah Tbk. Another obstacle that caused the ineffectiveness of the reclamation program their land tenure problem [17].

As the IUP holders, should the program run existing reclamation since mining is done the first time, but not finding reclamation reports to BLHD Bangka, so that there may be an indication that the reclamation activities conducted by PT. Timah Tbk has been less than the maximum [17].

Simply put, mining tin massively and massive in Bangka Island can be identified below:

a) Causing changes in the landscape of Bangka Island. Former mining tin mining, leaving a trail of big holes, which was then known as the 'pit', which spread almost throughout the mainland island of Bangka. These conditions make the island of Bangka be devastated island battered due to greedy exploitation of tin made in almost all the mainland island of Bangka.

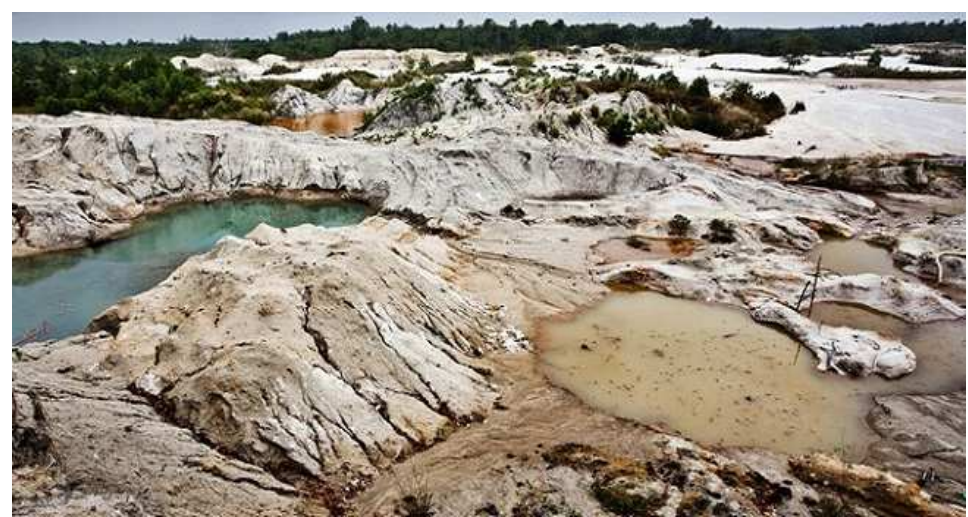

Fig. 1. Former mining tin mines spread around Bangka Island 
b) Causing damage to forests.

c) Led to declining soil fertility which then decrease the biological population.

d) Causing water pollution/river. Almost all rivers in Bangka Island has been used as storage of waste from the mining of tin, so although Bangka has many rivers, but the lack of clean water.

e) Water quality, aquatic habitat and diversity of fish in the Pacific lumber threatened.

f) Mining around the island causing damage to ecosystems and the extinction of aquatic biota.

g) Mining activities around the island causing dangerous heavy metal pollution and be toxic to aquatic resources and human impact is felt eventually.

\subsection{Millennial awareness related to environmental impacts of tin mining in Bangka}

The results showed that the awareness of the younger generation (the millennial generation) relating to the environmental impact of tin mining in Bangka quite high. Can be seen in the table below:

Table 1. Millennial Generation awareness of the Environmental Impacts of Mining Activities in Bangka Tin

\begin{tabular}{lcc}
\hline $\begin{array}{c}\text { Millennial Generation awareness of the environmental impact due to } \\
\text { mining tin in Bangka }\end{array}$ & Awareness & $\begin{array}{c}\text { Not } \\
\text { Awareness }\end{array}$ \\
\hline Tin mining led to the changing landscape of Bangka Island & $88.8 \%$ & $11.2 \%$ \\
\hline $\begin{array}{l}5 \% \text { of } 30 \% \text { of severe damage to forests in Bangka is the result of tin } \\
\text { mining (IT) }\end{array}$ & $83.2 \%$ & $16.8 \%$ \\
\hline $\begin{array}{l}\text { Mining activities cause soil degradation thus decrease the biological } \\
\text { population }\end{array}$ & $90.4 \%$ & $9.6 \%$ \\
\hline Mining cause a lot of damage to the environment, including rivers & $93.6 \%$ & $6.4 \%$ \\
\hline Bangka lack of clean water and it is due to mining activities & $76.8 \%$ & $23.2 \%$ \\
\hline $\begin{array}{l}\text { Water quality, aquatic habitat and diversity of fish resources in the } \\
\text { Pacific are threatened by mining }\end{array}$ & $81.6 \%$ & $18.4 \%$ \\
\hline $\begin{array}{l}\text { Almost all rivers in Bangka Island has been converted as a container for } \\
\text { waste from tin mining }\end{array}$ & $61.6 \%$ & $38.4 \%$ \\
\hline $\begin{array}{l}\text { Mining around the island causing damage to ecosystems and the } \\
\text { extinction of aquatic biota }\end{array}$ & $88.8 \%$ & $11.2 \%$ \\
\hline $\begin{array}{l}\text { Mining activities around the island causing dangerous heavy metal } \\
\text { pollution and be toxic to aquatic resources and ultimately impact felt by } \\
\text { humans }\end{array}$ & $81.6 \%$ & $18.4 \%$ \\
\hline
\end{tabular}

Source: Processed Data Researcher, 2019.

\subsection{Role of the Millennial Impact on Bangka Tin Mining Environment}

Most of the millennial as the younger generation has had a high awareness and concern about the environmental impact caused by tin mining in Bangka. It is best not reflected in real actions that they have done in the face of these issues, among others, as follows:

a) The majority of the millennial generation showed their concern by starting from ourselves to protecting the environment, such as; frugality in the use of water, reducing the use of plastic waste, reducing the risk of damage to the environment, care for the environment clean by not littering.

b) Intense socialization and hearings to the public and interested parties regarding the environmental impact caused by tin mining. 
c) Perform the literacy movement that people are more aware of the environmental impact of illegal mining.

d) Denounced the illegal mining activities, by way of protest and rejection of illegal mining in Bangka Island.

e) Socialize and conduct hearings to the public related to the damage caused by tin mining

f) Millennial generation who is currently studying mining engineering, generally already have a good knowledge and awareness that mining activities bring harm to the environment, but they have an alternative solution to overcome it. Here's one excerpt student majoring in mining engineering at the University of Bangka Belitung;

"I'm studying mining engineering, with a note that will be educating miners to implement MINING GOOD PRACTICE that tin mine did not hurt some parties or all of them. Better understand the importance of balance between environment and mining, self-awareness is required of each individual to minimize or eliminate illegal mines [IT] that can damage the land or sea environment Bangka island".

g) Reprimand/commemorates miners so as not to mine in Bangka

h) Denial/protest

i) Following the planting of a thousand trees in the IT file

j) Criticizing through social media

k) Join an organization that moves about the environment, the Environmental Forum (WALHI) and implement concrete action to rescue the environment by refusing to sea mines. Mobilizing people to resist sea mines.

1) Reported to the authorities when she saw illegal tin mining.

m) Learn well and seek knowledge in order later to know how mining is good and right to minimize damage environment by doing good mining practices, to create environmentally sound mining in Bangka Belitung.

But nonetheless, there is still a millennial generation that has apathy in addressing the problem of tin mining in Bangka. Despite claiming to be concerned, but quite many of them that are not/do not do anything to show their concern. In fact, some of them have a view that tin mining in Bangka is something that must be accepted, for better or worse. According to these circles, so far PT. Timah and Mining Company (private), others have contributed to the higher revenue in the area and is also considered to have a lot to contribute funding for students.

Some others, tend apathetic because they feel confused and do not know what to do. They argued that the issue should be resolved by the responsible party, so do not feel that the issue requires the participation of all parties to be resolved.

Meanwhile, the percentage of students who engage in 'action' demands on issues related to government mining and environmental impact can be seen in the following diagram:

Percentage of Student Involvement in actions demanding the government related to mining isues andenviromental impacts

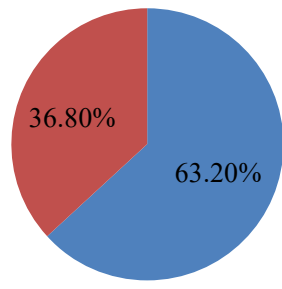

- Take Action

- Not Take Action 


\section{Conclusion}

Tin mining on Bangka Island has caused Bangka to become a 'battered' area. Various environmental impacts due to mining activities become something that cannot be denied. Controversial debates continued without end, while mining activities continued. Many landscapes in Bangka that have changed due to mining activities to leave the former excavation holes scattered throughout the island of Bangka. The environmental impact caused by tin mining activities is continuously felt by the community.

Young generation in Bangka already have sufficient awareness and knowledge of the problem. It's just that at this time they haven't been able to do much to change the existing conditions. All they can do is start protecting the environment from themselves and raise awareness of the people around them by moving literacy, conducting socialization, hearing to the tin mining community, also showing rejection/protest actions to the government through social media and demonstrations.

\section{References}

[1] E. Erman, “Actor, Access and Environmental Politics at Bangka Tin Mining," Indones. Soc. J., vol. 36, no. 2, pp. 71-101, 2010.

[2] E. H. Prianto, "Unconventional Tin Mining: Impact on Biodiversity of public water damage on the island of Bangka," POMFRET, vol. 2, no. 5, pp. 193-198, 2009.

[3] B. Meyana, Lia; Sudadi, Lucky; Tjahjono, "Tutorial and Development Strategy LoggedTambang Timah As PremÂise in Bangka,” J. Nat. Resour. Environ. Manag., vol. 5, no. 1, pp. 51-60, 2015.

[4] F. Epp, Schilderungen aus Holländisch-Ostindien. Winter, 1852.

[5] J. A. Schuurman, Historische schets van de tinwinning op Banka. Algemeene Landsdrukkerij, 1898.

[6] K. Helbig, "Die Insel Bangka," Sonderdruck aus Dtsch. Geogr. Blätter, vol. 43, no. 3-4, 1940.

[7] D. Hyndman, "Shifting Ecological Imaginaries in the Ok Tedi Mining Crisis in Papua New Guinea," J. Soc. Ocean., no. 120-121, pp. 76-93, 2005.

[8] S. Kirsch, "Indigenous movements and the risks of counterglobalization: tracking the campaign against Papua New Guinea's Ok Tedi mine," Am. Ethnol., vol. 34, no. 2, pp. 303-321, 2007.

[9] S. GITOSUWONDO, "Environment Friendly Open Pit Mining Systems and Reclamation PostMining Efforts to Improve the Quality of Land Resources and Soil Biodiversity," J. Sumberd. Lahan, vol. 5, no. 02, 2017.

[10] A. Dariah, A. Abdurachman, and D. Subardja, "Reklamasi lahan eks-penambangan untuk perluasan areal pertanian," J. Sumberd. Lahan, vol. 4, no. 1, pp. 1-12, 2010.

[11] H. H. Finnel, "The dust storms of 1954," Sci. Am., vol. 191, no. 1, pp. 25-29, 1954.

[12] M. A. Alonso-Zarazaga, "Fauna Europaea." Coleoptera, 2011.

[13] J. B. C. Jackson and E. Sala, "Unnatural Oceans," Sci. Mar., vol. 65, no. S2, pp. 273-281, 2001.

[14] T. H. Ji, M. Grossmann, and I. Ji, "G protein-coupled receptors I. Diversity of receptor-ligand interactions," J. Biol. Chem., vol. 273, no. 28, pp. 17299-17302, 1998.

[15] A. Vila-Gispert, R. Moreno-Amich, and E. Garcia-Berthou, "Gradients of life-history variation: an intercontinental comparison of fishes," Rev. Fish Biol. Fish., vol. 12, no. 4, pp. 417-427, 2002.

[16] K. Muslih, E. M. Adiwilaga, and S. Adiwibowo, "Pengaruh Penambangan Timah Terhadap Keanekaragaman Ikan Sungai Dan Kearifan Lokal Masyarakat Di Kabupaten Bangka," LIMNOTEK-Perairan Darat Trop. di Indones., vol. 21, no. 1, 2016.

[17] I. Sari, Dian Permata; Buchori, "Post-Mining Reclamation Program Effectiveness in the District Merawang Timah Bangka," J. Reg. Dev. City, vol. 11, no. 2, pp. 299-312, 2015. 